\title{
Failure of Named Representatives in a Class Action to Satisfy the Statute of Limitations
}

\author{
Gordon M. Mead, Jr. $\dagger$
}

Consider the following scenario: A named plaintiff files a class action suit on behalf of hundreds of tenants for breach of contract against a large residential landlord. The complaint alleges that the landlord has breached the terms of the lease by refusing to keep the apartments in a decent state of repair. The named representative has clearly failed to file her individual complaint within the relevant twoyear statute of limitations, but the complaint describes a class composed of some individuals who satisfy the statute of limitations and others who fail the statute of limitations.

Can a district court consider the named representative's failure to satisfy the statute of limitations at the certification stage of a class action suit? The United States Court of Appeals for the Fourth Circuit prohibits district courts from considering time bars to the named representative's claim at certification. The Fourth Circuit reasons that federal courts do not have the authority to consider a plaintiff's chances of success on the merits at certification. ${ }^{2}$ Several district courts, however, have considered the named representative's time bar prior to certification. These courts reason that Federal Rule of Civil Procedure 23 ("Rule 23") explicitly grants district courts the power to evaluate all factual and legal claims relevant to certification."

Under the approach suggested by the Fourth Circuit, a district court must ignore the named representative's time bar at certification. The district court grants certification and orders the class representative and attorney to send out notice to absent class members. The par-

$\dagger$ B.A.1998, Dartmouth College; J.D. Candidate 2001, The University of Chicago.

1 Assume that a federal district court has jurisdiction because the parties are diverse. See 28 USC $\$ 1332$ (1993 \& Supp 1999).

2 See International Woodworkers of America v Chesapeake Bay Plywood Corp, 659 F2d 1259,1270 (4th Cir 1981) ("Courts passing upon motions for class certification have generally refused to consider the impact of such affirmative defenses as the statute of limitations on the potential representative's case."). See also Goodman v Schlesinger, 584 F2d 1325, 1332 (4th Cir 1978) (holding "that the district court acted prematurely in denying class certification"). See also Part I.D.

3 See Commander Properties Corp v Beech Aircraft Corp, 164 FRD 529, 538-39 (D Kan 1995) (deciding that the unique time bar prevented the representative from satisfying Rule 23(b)(3)'s predominance requirement); Sperling $v$ Donovan, 104 FRD 4, 9 (D DC 1984) (declaring certification inappropriate and evaluating the named plaintiff's time bar under Rule 23(a)(3)'s typicality requirement). See also Part I.D. 
ties and the court then begin the costly and time-consuming discovery process.

After certification, notice, and discovery, the defendant files a motion for summary judgment against the class representative on the basis of the statute of limitations defense. The district court predictably grants summary judgment against the representative. At this point, courts and commentators can agree that the representative is unfit. The delay, however, has created a Hobson's choice for the district court: Either decertify the class or allow the substitution of a new representative.

If the district court decertifies, then the notice, discovery, and litigation costs to date are wasted. Automatically allowing substitution, on the other hand, creates four problems: First, a representative's inadequate representation or atypical legal claims can often signal classwide internal difficulties that substitution cannot remedy. ${ }^{5}$ Second, certification itself will create pressure for a settlement that ignores differences between class members with timely and others with timebarred claims. ${ }^{6}$ Third, routine substitution may deny the defendant adequate notice of the type and scope of her liability before the statute of limitations has run. F Fourth, automatic substitution reinforces the incentives for class attorneys to name a single representative hastily. Multiple and diverse representatives would give the district court better information about the individuals who constitute the class, facilitating more effective case management. ${ }^{8}$

This Comment proposes that federal district courts investigate a named representative's time bar at certification. If the statute of limitations bars the named representative's claim, the district court should only certify for clearly specified, compelling reasons. District courts should also adopt a presumption towards striking the class complaint when the statute of limitations bars the named representative's claims.

Part I explains the procedure for selecting named representatives and certifying a class action. It details the sequence of events leading to the district court's discovery of the named representative's time bar. Part II describes how the time-barred representative can fail to satisfy the requirements of Rule 23. Part III recommends evaluating

4 See, for example, Eisen v Carlisle \& Jacquelin, 417 US 156, 167 (1974) (describing substantial notice costs). See also Part III.A.2.

5 See Part II for a discussion of a time bar's implications for the named representative's typicality and adequacy. See Part III.A.2 for a discussion of the implications for the broader class.

See Part III.A.2.

See Part III.A.3.

See Part III.B.1. 
these issues at certification and adopting a presumption towards striking the class complaint if the district court refuses certification.

\section{COMPETING APPROACHES TO THE FAILURE OF THE NAMED REPRESENTATIVES TO SATISFY THE STATUTE OF LIMITATIONS}

Federal courts have approached the time-barred representative differently, but some generally accepted principles about class actions and statutes of limitations underlie their decisions. The class action device combines the legal claims of many individual plaintiffs to conserve both judicial and litigant resources. Although aggregating these claims can streamline justice and vindicate the legal claims of absent class members, the class action device poses special due process problems. Rule 23 attempts to curb the potential for abuse by establishing unique procedural safeguards for class action suits. As part of these unique safeguards, certain class members must step forward and actively participate in the suit.' These class members, or named representatives, have the opportunity to supervise the class attorney actively. ${ }^{10}$ More importantly, named representatives provide the district court with salient, prototypical, and concrete examples of class members.

The district court will usually consider Rule 23 requirements in a special certification hearing. The certification hearing will determine whether the action can be brought as a class action." Even after the certification hearing, however, the district court retains the discretion to limit the size of the class, force a clearer definition of the class, require the substitution of current representatives, or decertify and strike the class complaint. ${ }^{12}$

Time-barred representatives can fail to satisfy Rule 23 requirements. Courts disagree over whether a district court can consider the timeliness of a representative's claim at certification. The Fourth Circuit, for instance, prohibits district courts from evaluating a representative's time bar at certification. The Fourth Circuit seeks to preserve the independence of certification hearings: a certification hearing should not become a truncated decision on the merits. ${ }^{13}$ Deciding the

9 For a general description of the origins of class action devices and the mechanism of Rule 23, including its method for alleviating due process concerns, see John J. Cound, et al, Civil Procedure: Cases and Materials 682-88 (West 7th ed 1997). See also Part I.A.

10 See Part I.A.

11 FRCP 23(c)(1) (directing district courts to determine whether an action should be brought as class action "[a]s soon as practicable"). See also Cound, et al, Civil Procedure at 69394 (cited in note 9). See also Part I.B.

12 FRCP 23(d) (describing the substantial managerial powers of the district court when conducting a class action); Charles Alan Wright, Arthur R. Miller, and Mary Kay Kane, 7B Federal Practice and Procedure $\$ 1794$ at 313 (West 2 d ed 1998) (same). See also Part I.B.

13 See, for example, International Woodworkers of America $v$ Chesapeake Bay Plywood Corp, 659 F2d 1259, 1270 (4th Cir 1981) (holding that "the district court acted prematurely in 
underlying validity of the claims too early will compromise the procedural safeguards of a full trial. ${ }^{14}$ Some district courts, however, emphasize resolving the fitness of the named representative "as soon as practical." Delaying the resolution of issues critical to certification threatens to compromise the efficiency goals of Rule 23. Delay may have fairness implications as well. ${ }^{16}$ As a result, these district courts evaluate statute of limitations defenses at certification. This Part describes the goals and operation of statute of limitations in the class action device to help evaluate these competing claims.

\section{A. The Named Representative's Role in a Federal Class Action}

The federal class action enables large numbers of people to aggregate similar claims, for either damages or injunctions, in a single lawsuit. ${ }^{17}$ Hundreds and sometimes thousands of individual plaintiffs, or class members, obviously cannot participate in the direction of the suit in the same way that individual plaintiffs participate in a traditional lawsuit. Instead, the district court selects one or more individuals from the class to participate in the litigation and to protect the interests of other class members. These individuals, or named representatives, must satisfy several requirements outlined by Rule $23 .^{18}$

Most importantly, the named representatives must adequately protect the interests of the class and present typical legal claims. ${ }^{19}$ The Due Process Clause requires the selection of named representatives and class attorneys who will effectively guard the property interests of absent class members. ${ }^{20}$ As the most involved class members, the named representatives can more effectively influence the class attor-

denying class certification" when the class representative's complaint was time-barred). See also Part I.D.

14 See Eisen v Carlisle \& Jacquelin, 417 US 156, 178 (1974) ("[A] preliminary determination of the merits may result in substantial prejudice to a defendant, since of necessity it is not accompanied by the traditional rules and procedures applicable to civil trials."). See also Part I.D and Part III.A.4.

15 FRCP 23(c)(1) (mandating a certification decision "[a]s soon as practicable"). See, for example, Commander Properties Corp v Beech Aircraft Corp, 164 FRD 529, 537 (D Kan 1995) (considering the implications of a named representative's time bar for purposes of certification); Sperling v Donovan, 104 FRD 4, 9 (D DC 1984) (declaring time-barred representatives atypical and refusing certification). See also Part I.D.

16 See Part III.A.2 and Part III.A.3.

17 Rule 23 enables the class to seek either damages or equitable relief This Comment will focus on Rule 23(a)'s general requirements in the context of a suit for damages. When a class seeks uniform equitable relief, different issues may arise.

18 FRCP 23(a)-(b); Cound, et al, Civil Procedure at 689-93 (cited in note 9).

19 FRCP 23(a)(3) (typicality); FRCP 23(a)(4) (adequacy).

20 Phillips Petroleum Co $v$ Shutts, 472 US 797, 812 (1985) ("TT]he Due Process Clause of course requires that the named plaintiff at all times adequately represent the interests of the absent class members."). 
ney and participate in major litigation decisions. ${ }^{21}$ As the most salient class members, the named representatives offer the district court concrete examples of the legal claims of the broader class. ${ }^{2}$ The named representatives' disproportionate influence over the class attorney and court require carefully aligning the interests of named representatives and absent class members.

In a large, complex class action suit, a single representative may be unable to represent the spectrum of individual claims that compose the class. Both Rule 23 and federal courts contemplate that several named representatives, with slightly different legal or factual claims, might represent the claims of the class more effectively. ${ }^{23}$ Consequently, larger and more diverse classes will often have multiple representatives.

21 The Supreme Court has expressed concern when attorneys name representatives only after determining the rough shape of the final settlement. Ortiz v Fibreboard Corp, 527 US 815, 119 S Ct 2295, 2319 n 31 (1999). The Fifth Circuit has also relied on the named representatives to make decisions advancing the interests of the broader class. See Pettway v American Cast Iron Pipe Co, 576 F2d 1157, 1177-78 (5th Cir 1978) (deciding that the initial decision to appeal should presumptively rest with the class representatives, although the class attorney should be able to bring arguments before the court that might protect the interest of absent class members). Some academics have criticized the vision of the named representative as active monitor. The named representative has a small stake in the outcome, is usually chosen by the attorney, and the attorney avoids named representatives that will exert significant control. See Jonathan R. Macey and Geoffrey P. Miller, The Plaintiffs' Attorney's Role in Class Action and Derivative Litigation: Economic Analysis and Recommendations for Reform, $58 \mathrm{U}$ Chi L Rev 1, 41 (1991). The named representative is unlikely to complain about a class attorney's conduct. Thus, when the named representative actually does complain, perhaps courts should pay close attention. Id at $42-43$. Because the named representative has a limited incentive to monitor actively, a complaint from the representative signals particularly egregious behavior by a class attorney. The named representative's monitoring role could be seen as a supplemental safeguard embedded in Rule 23.

22 Even harsh critics of the named representative device admit that a review of "exemplary class members" is necessary for the district court to make decisions about personal jurisdiction, standing, and administrative requirements. Jean Wegman Burns, Decorative Figureheads: Eliminating Class Representatives in Class Actions, 42 Hastings L J 165, 194-95 (1990).

23 The text of Rule 23(a) references the possibility that multiple individuals may serve as class representatives. FRCP 23(a) ("One or more members of a class may sue or be sued as representative parties" if they satisfy the general requirements of Rule 23(a)). The Supreme Court has long noted that a single representative might fail to represent adequately the interests of a class when multiple representatives could adequately represent those interests. General Telephone Co of the Southwest $v$ Falcon, 457 US 147, 157-60 (1982) (noting a wide divergence between the single named representative's claim of discriminatory denial of promotion and some class members' claims of discriminatory hiring practices). The Supreme Court more recently noted that when substantial factual differences between members of the class exist, the district court should create subclasses and name separate plaintiffs to represent each subclass. Amchem Products, Inc v Windsor, 521 US 591, 626-27 (1997) (noting the failure of the district court to create subclasses and address factual difficulties).

24 See, for example, In re Rhone-Poulenc Rorer, Inc, 51 F3d 1293, 1296-97 (7th Cir 1995) (describing a class action on behalf of all hemophiliacs in the United States infected with HIV from the blood supply as represented by multiple named representatives). 
B. Selection of Named Representatives and the Certification of the Class

The plaintiffs' attorney generally recommends one or more named representatives to the district court. ${ }^{25}$ As soon as practical, the district court holds a certification hearing to determine the fitness of the named representatives. ${ }^{26}$ At the certification hearing, the district court has three options. First, a district court can grant certification if the named representative clearly satisfies Rule 23 requirements. ${ }^{27}$ Second, a district court can grant conditional certification if it lacks the evidence to refuse certification but fears that fuller discovery or subsequent events will reveal the named representatives' unfitness. ${ }^{25}$

Third, the district court can refuse certification if the named representatives clearly fail to satisfy Rule 23 requirements. Upon refusing certification, the district court can either dismiss the class complaint or order remedial steps. Remedial steps might include limiting the size of the class, forcing the plaintiffs' attorney to more clearly define the scope of the class complaint, or allowing the substitution of other class members as named representatives. ${ }^{29}$ If the district court orders remedial steps, the district court will almost certainly grant certification after the plaintiffs' attorney has complied with its order. ${ }^{30}$ After the district court grants certification, the plaintiffs' attorney will send notice of the action to absent class members, and full discovery will begin as the parties proceed to trial.

\section{The Purpose and Operation of Statutes of Limitations}

Statutes of limitations require plaintiffs to file suit within a specified period of time after the defendant's wrongful conduct. If the plaintiffs fail to file suit within that time period, courts refuse to consider the underlying validity of the cause of action. ${ }^{31}$ Statutes of limitations prevent the deterioration of evidence, facilitate fairness to de-

25 Cound, et al, Civil Procedure at 688 (cited in note 9).

26 See note 11.

27 FRCP 23(c)-(d); Cound, et al, Civil Procedure at 693-94 (cited in note 9).

28 FRCP 23(c)(1) (describing the certification order as conditional and subject to amendment at any time before a decision on the merits); General Telephone Co of the Southwest $v$ Falcon, 457 US 147, 160 (1982) ("Even after a certification order is entered, the judge remains free to modify it in the light of subsequent developments in the litigation.").

29 See notes 130-33.

30 FRCP 23(c)-(d); Cound, et al, Civil Procedure at 693-94 (cited in note 9).

31 Order of Railroad Telegraphers $v$ Railway Express Agency, 321 US 342, 348-49 (1944) (describing the operation and purpose of statutes of limitations). For a general discussion of statutes of limitations, see Tyler T. Ochoa and Andrew J. Wistrich, The Puzzling Purposes of Statutes of Limitations, 28 Pac L J 453 (1997). 
fendants, ${ }^{32}$ punish plaintiffs for sleeping on their rights, ${ }^{33}$ and reduce the strain on the judicial system. ${ }^{34}$

Statutes of limitations are usually procedural. They prescribe a period of time during which the plaintiff may bring suit without setting any limits on the existence of the legal right itself ${ }^{35}$ Procedural statutes of limitations are both waivable and subject to traditional equitable exceptions. ${ }^{36}$ Sometimes, however, statutes of limitations may circumscribe the right itself. Substantive or jurisdictional statutes of limitations are sometimes termed statutes of repose. Time limits on state wrongful death statutes are often characterized as time limits upon the actual substantive right. ${ }^{37}$ States have enacted statutes of repose designed to shield manufacturers from product liability suits a certain number of years after the product has been marketed, regardless of when the injury occurred. These statutes are often considered limitations on the right itself. ${ }^{38}$

\section{The Failure of Named Representatives to Satisfy the Statute of Limitations}

Because class actions involve the aggregation of many individual claims over time, statutes of limitations will often bar the claims of some class members while permitting the claims of other class members. $^{39}$ Frequently, named representatives fail to satisfy the statute of

32 United States $v$ Kubrick, 444 US 111, 117 (1979) (emphasizing fairness to the defendant and preservation of evidence); Order of Railroad Telegraphers, 321 US at 348-49 (emphasizing the importance of preventing surprise, preserving evidence, and placing the defendant on notice).

33 American Pipe \& Construction Co v Utah, 414 US 538, 554-55 (1974) (recognizing the need to punish plaintiffs who have slept on their rights).

34 Bumett v New York Central Railroad Co, 380 US 424, 428 (1965) ("[T] he courts ought to be relieved of the burden of trying stale claims when a plaintiff has slept on his rights.").

35 Zipes $v$ Trans World Airlines, Inc, 455 US 385, 398 (1982) (describing the time limits embodied in Title VII of the 1964 Civil Rights Act as procedural rather than jurisdictional and subject to equitable exceptions); Cedars-Sinai Medical Center $v$ Shalala, 125 F3d 765, 770-71 (9th Cir 1997) (holding that a statute must explicitly describe the time limit as jurisdictional in order for it to be jurisdictional).

36 Zipes, 455 US at 398. Many jurisdictions will toll the statute of limitations if the defendant is absent from a jurisdiction during the statutory period or fraudulently conceals the tortious wrong. Many jurisdictions will also toll the statute of limitations if the plaintiff suffers from a personal disability or incapacity to sue, such as infancy or mental incapacity. For a description of traditional equitable exceptions, see Geoffrey C. Hazard, Jr., Colin C. Tait, and William A. Fletcher, Pleading and Procedure: State and Federal Cases and Materials 132-33 (Foundation 8th ed 1999).

37 Symeon C. Symeonides, Wendy Collins Perdue, and Arthur T. von Mehren, Conflict of Laws: American, Comparative, International: Cases and Materials 374 (West 1998).

38 See, for example, Love $v$ Whirlpool Corp, 449 SE2d 602, 606-07 (Ga 1994) (characterizing Georgia's products liability statute of repose as a limitation on the scope of the right itself).

39 See, for example, National Assn of Govt Employees v City Pub Serv Bd of San Antonio, 40 F3d 698,716 (5th Cir 1994) (stating in the context of a Title VII class action that "[p]utative class members whose grievances are barred by the statute of limitations ... cannot be counted 
limitations and their claims are therefore time-barred. ${ }^{40}$ Sometimes, all of the named representatives fail to satisfy the statute of limitations." Courts and commentators disagree over whether to consider time bars to the named representative's action at the certification hearing. Some courts evaluate time bars to the named representative's action at certification. These courts carefully consider whether the time bar will render the named representative inadequate or her legal claims atypi$\mathrm{cal}^{42}$ If the district court concludes that the time bar does not compromise the named representative's ability to represent the class, then the court can certify or conditionally certify the class action. If the court concludes that the time bar renders the named representative unfit, then the district court can either allow substitution or intervention by a class member who satisfies the statute of limitations, limit the size of the class, or strike the class complaint. ${ }^{4}$

Other courts refuse to consider the named representative's failure to satisfy the statute of limitations at certification. ${ }^{45}$ These courts

toward computation of the class").

40 This Comment focuses on cases where all of the representatives fail to satisfy the statute of limitations. As long as a single remaining representative satisfies the statute of limitations, the district court will probably allow the action to continue. Aguirre v Bustos, 89 FRD 645, 648 (D NM 1981) (severing one named plaintiff because of inadequacy and allowing the others to remain); Wright, Miller, and Kane, 7A Federal Practice and Procedure $\$ 1765$ at 277-78 n 34 (cited in note 12) (noting that there is "[o]nly one representative needed").

41 See, for example, Davis v Bethlehem Steel Corp, 600 F Supp 1312, 1322-23 (D Md 1985) (noting that all four named representatives failed to satisfy the statute of limitations).

42 See, for example, Commander Properties Corp v Beech Aircraft Corp, 164 FRD 529, 537 (D Kan 1995) (considering the impact of the representative's time bar on Rule 23 requirements); Sperling v Donovan, 104 FRD 4, 9 (D DC 1984) (declaring time-barred representatives atypical and refusing certification).

43 See, for example, Rodger $v$ Electronic Data Systems Corp, 160 FRD 532, 538-39 (E D NC 1995) (certifying a class action after finding that statute of limitations defenses specific to named representatives did not render them atypical).

44 See, for example, International Woodworkers of America v Chesapeake Bay Plywood Corp, 659 F2d 1259, 1270 (4th Cir 1981) (reversing the district court's dismissal of class complaint to allow substitution by non-time-barred class members). See also Cound, et al, Civil Procedure at 694-95 (cited in note 9) (describing the options of the district court after a denial of certification).

45 International Woodworkers, 659 F2d at 1270 (admitting that disqualifying the named representative after summary judgment would be appropriate, but refusing to allow the district court to consider the issue at certification); In re VMS Securities Litigation, 136 FRD 466, 477 (N D Ill 1991) ("Finally, inasmuch as the statute of limitations defense addresses the merits of plaintiffs' claims, it is beyond the scope of a motion for class certification."); In re Baldwin-United Corp Litigation, 122 FRD 424, 427 (S D NY 1986) (ruling that individual questions of timeliness should not be decided at the certification stage); Dameron $v$ Sinai Hospital of Baltimore, Inc, 595 F Supp 1404, 1408-09 (D Md 1984) (classifying the statute of limitations as an affirmative defense that should not be considered prior to certification); Herbert Newberg, 3 Newberg on Class Actions $\$ 3.16$ at 93 (Shepard's 1992) ("[T] he class representative need not show a probability of individual success on the merits."). See also Goodman $v$ Schlesinger, 584 F2d 1325, 1332 (4th Cir 1978) (deciding that the district court acted prematurely in denying certification to the entire class when it disqualified the three named plaintiffs). 
rely on the Supreme Court's decision in Eisen v Carlisle \& Jacquelin for the proposition that district courts should not evaluate the plaintiff's likelihood of success on the merits at certification. ${ }^{47}$ In Eisen, the district court held a preliminary hearing on the merits of the plaintiffs' claims, and, after determining that the plaintiff was "more than likely" to prevail on the merits, forced the defendants to bear 90 percent of the notice costs. The Supreme Court reversed the imposition of notice costs, remarking that nothing in Rule 23 gives the district court the authority to conduct a hearing on the merits. The Supreme Court worried that allowing such a procedure would defeat the purpose of the Rule 23 requirements by allowing the named representative to obtain the advantages of a class action before satisfying Rule 23's requirements for representation. The Supreme Court also expressed concern that a preliminary trial on the merits would deprive the defendant of the procedural and evidentiary safeguards applicable only to a full trial.

Courts concerned about the Eisen restriction on evaluating the merits of the claim before certification defer statute of limitations issues until the parties file cross-motions for summary judgment. ${ }^{49}$ If the court grants summary judgment against the named representatives prior to trial, then the court must resolve the status of the class action. ${ }^{\text {so }}$ At this point, the court can allow substitution by other class members, limit the size of the class, or decertify the class.

46417 US 156 (1974).

47 Id at $177-78$.

48 Id.

49 The Second Circuit and the Sixth Circuit have allowed district courts to decide motions for summary judgment against named representatives before the certification hearing. See Schweizer v Trans Union Corp, 136 F3d 233,239 (2d Cir 1998) ("The decision to award summary judgment before acting on class certification was well within the discretion of the district court."); Jibson v Michigan Education Association-NEA, 30 F3d 723, 734 (6th Cir 1994) (allowing the district court to resolve a single issue in the case at summary judgment before addressing the issue of certification). A district court might be able to use this device to dismiss a time-barred named representative before certification, but it has several limitations. First, some courts refuse to allow it. See Peritz v Liberty Loan Corp, 523 F2d 349, 353-55 (7th Cir 1975) (declaring the procedure violative of Eisen's prohibition against evaluating claims on the merits at certification). Second, a motion for summary judgment against the named representative alone will not resolve any of the issues relating to the class. See Smith v Shawnee Library System, 60 F3d 317, 322 (7th Cir 1995) (refusing to grant class-wide effects to summary judgment against named representative because lack of effective certification voided initial certification decision). Both the plaintiff and defendant may desire to resolve the issues in the context of the certification decision. Part II suggests that the named representative's time bar will often interact with Rule 23 in complex ways, and the defendant may be reluctant to divorce those inquiries. Finally, a defendant may be reluctant to bring a motion for summary judgment against a single individual very early in the litigation, before full discovery, because she wishes to bring the motion on other grounds in the alternative.

50 The Fourth Circuit has disqualified representatives after granting the defendant's motion for summary judgment but refused to grant district courts the power to determine those issues at certification. See, for example, International Woodworkers, 659 F2d at 1270. 


\section{A TiME BAR to tHE NAMED REPRESENTATIVES' ACTION CAN CREATE SUBSTANTIAL PROBLEMS UNDER RULE 23(A)}

The failure of all of the named representatives in a class action to satisfy the statute of limitations can create several difficulties under Rule 23. Rule 23(a) describes the general requirements for the maintenance of a class action. ${ }^{\text {s1 }}$ A time bar to the named representatives' action may create three problems under the general Rule 23(a) requirements.

First, Rule 23(a) implicitly requires that the class representative be a member of the class. If the named representative's claims are time-barred, she may cease to be a member of the class. ${ }^{52}$ Second, Rule 23(a)(3) requires that the representative's legal claims be typical of class members' legal claims. In some cases, the named representative's vulnerability to a statute of limitations defense may make her legal claims markedly different from those of absent class members. ${ }^{53}$ Third, Rule 23(a)(4) requires that a representative fairly and adequately protect the interests of the class. A time-barred representative will usually lack the incentives to vigorously protect the interests of the class. The failure of the named representative to satisfy the statute of limitations might also create conflicts of interest between the named representative and absent class members. ${ }^{4}$ Thus, the failure of the named representative to satisfy the statute of limitations may raise substantial problems with Rule 23(a)'s general requirements for the maintenance of a class action.

$\begin{array}{ll}51 & \text { FRCP 23(a). } \\ 52 & \text { See Part II.A. } \\ 53 & \text { See Part II.B. } \\ 54 & \text { See Part II.C. }\end{array}$

55 The district court must also sort the class action into one of three categories outlined in Rule 23(b). The district court may label the action a Rule 23(b)(3) mass tort class action, where the only unifying feature is that the defendant has injured all of the class members in the same way. Rule 23(b)(3) has two more stringent requirements: First, questions of law or fact common to the class members must predominate over questions affecting individual class members. Second, the district court must find that the "class action is superior to other available methods for the fair and efficient adjudication of the controversy." FRCP 23(b)(3). If the representative cannot satisfy the general requirements of 23(a), the representative will obviously not satisfy the requirements of Rule 23(b)(3). More interestingly, district courts have used the requirements of Rule 23(b)(3) to deny certification despite finding that the named representatives satisfied the more general requirements of Rule 23(a). These courts raised the same arguments used in the adequacy and typicality context, but they concluded that in the individual case they create lesser problems that only rise to the level of compromising predominance and superiority. See, for example, Harding $v$ Tambrands Inc, 165 FRD 623, 629-30 (D Kan 1996) (illustrating that in a case of ongoing or continuous harm the representative's time bar may be more likely to coincide with difficult choice of law problems that undermine superiority). 


\section{A. Class Membership}

A time bar may prevent a plaintiff from being a member of the class, making her unfit to serve as the sole named representative. The Supreme Court has ruled that "a class representative must be part of the class and 'possess the same interest and suffer the same injury' as the class members." "fairly encompassed within the named plaintiff's claim," and the district court should examine the pleadings, evidence introduced for certification, and evidence uncovered during discovery to determine the representative's class membership."

Courts that have addressed the issue unanimously agree that a time-barred named representative is not "part of the class." "The functional justifications underlying the class membership requirement provide a persuasive reason to refuse certification. The named representative's time bar deprives her of any interest in the outcome of the litigation; her interests fundamentally diverge from the interests of absent class members with timely claims. ${ }^{\text {s9 }}$ The courts cannot trust a named representative without a vested interest in the outcome of the litigation to monitor the plaintiffs' attorney actively or to provide a realistic example of the class's legal claims to the district court. ${ }^{80}$ The Fourth Circuit and Eighth Circuit properly decided that a named representative who fails to satisfy the statute of limitations is not a member of the class.

The class membership requirement is closely related to Rule 23's other requirements. The Supreme Court reasoned that the named representative's lack of class membership raises problems of commonality, typicality, and adequacy. ${ }^{61}$ By looking to the named representative's class membership, the district court can more easily determine

56 East Texas Motor Freight System, Inc v Rodriguez, 431 US 395, 403 (1977), quoting Schlesinger v Reservists Committee to Stop the War, 418 US 208, 216 (1974). For a general discussion, see Wright, Miller, and Kane, 7A Federal Practice and Procedure $\S 1761$ at 132-50 (cited in note 12).

57 General Telephone Co of the Southwest v Falcon, 457 US 147, 160 (1982).

58 See Great Rivers Cooperative v Farmland Industries, Inc, 120 F3d 893, 899 (8th Cir 1997) (refusing to certify a class when the named plaintiff clearly had inquiry notice and thus was timebarred); Weinberger $v$ Retail Credit Co, 498 F2d 552, 556 (4th Cir 1974) (refusing to allow the time-barred named plaintiff to serve as class representative); Mason v Anheuser-Busch, Inc, 579 F Supp 871,873 n 1 (ED Mo 1984) ("[P]laintiff is precluded from being a member of such a class because his action is time-barred.").

59 See notes 72-73.

60 See notes $21-22$.

61 Falcon, 457 US at 157-58 \& n 13 (noting the interrelatedness of commonality, typicality, and adequacy requirements); East Texas Motor Freight, 431 US at 405-06 ("The mere fact that a complaint alleges racial or ethnic discrimination does not in itself ensure that the party who has brought the lawsuit will be an adequate representative of those who may have been the real victims of that discrimination."). 
"whether under the particular circumstances maintenance of a class action is economical and whether the named plaintiff's claim and the class claims are so interrelated that the interests of the class members will be fairly and adequately protected in their absence." ${ }^{12}$

\section{B. Typicality}

In some cases, the availability of a statute of limitations defense will render the time-barred plaintiff's legal claims atypical. Rule 23(a)(3) requires that "the claims or defenses of the representative parties" be "typical of the claims or defenses of the class." Usually, the plaintiff is deemed to have satisfied Rule 23(a)(3) if the claims or defenses of the representatives and class members either stem from the same event or propose the same legal or remedial theory. ${ }^{63}$ Under this view, Rule 23(a)(3) is used to screen out class actions where the legal or factual position of the representative is markedly different from that of other members of the class despite the existence of common issues of law or fact. ${ }^{A}$

Federal courts are divided over whether a district court should deny certification on typicality grounds when a named representative fails to satisfy a procedural statute of limitations. Some courts have reasoned that a named representative with a defense unique to her is not an appropriate class representative. ${ }^{65}$ Other courts have decided that statute of limitations problems may create management difficulties, but these management difficulties do not rise to the level of defeating typicality.

62 Falcon, 457 US at $157 \mathrm{n} 13$.

63 See Hilao $v$ Estate of Marcos, 103 F3d 767, 774 (9th Cir 1996) (certifying a class of alleged victims of torture because all claims rested on the theory that the former president was responsible for the torture, allowing the district court to resolve all individual statute of limitations questions in a single, legal determination); Consolidated Rail Corp v Hyde Park, 47 F3d 473, 483 (2d Cir 1995) (finding that the defense of the named representative was typical of class defenses when "[e]ach member of the defendant class participate[d] in New York's system of taxation"); Baby Neal for and by Kanter $v$ Casey, 43 F3d 48, 58 (3d Cir 1994) (finding that named representatives could allege systematic failure of child care services on behalf of the class despite the fact that services required by law depended on the status of each individual child).

64 See Hill $v$ Western Electric Co, Inc, 596 F2d 99, 101-02 (4th Cir 1979) (holding that the interest of named plaintiffs in being free of discrimination in promotion and job assignments was so different from class members' interest in avoiding discriminatory hiring as to render named plaintiffs atypical).

65 See Hardy $v$ City Optical Inc, 39 F3d 765, 770 (7th Cir 1994) (acknowledging that a legal defense unique to the named representative could make her atypical); Sperling $v$ Donovan, 104 FRD 4, 9 (D DC 1984) (ruling that time bar to named representatives' action rendered them atypical).

66 Wagner $v$ Nutrasweet Co, 95 F3d 527, 534 (7th Cir 1996) (referring to the defendant's actions rather than statute of limitations defenses against class members to determine typicality); Harding $v$ Tambrands Inc, 165 FRD 623, 628-29 (D Kan 1996) (deciding that differing statutes of limitations did not rise to the level of defeating typicality); Commander Properties Corp $v$ Beech Aircraft Corp, 164 FRD 529, 537 (D Kan 1995) (classifying the statute of limitations concern as 
District courts seem particularly likely to declare the time-barred named representative atypical in two circumstances. First, if the named representative is only one of a few members of the class who suffers from the statute of limitations defect, then the district court will be more willing to declare her atypical. ${ }^{67}$ Second, if the district court suspects that individualized limitations defenses will dominate the litigation, the district court will be more willing to declare the representative atypical. ${ }^{68}$ Although these decisions will be highly factspecific, a time bar to the named representative's action can create typicality problems.

\section{Adequacy}

A time bar may prevent a plaintiff from adequately guarding the interests of other class members. Rule 23(a)(4) requires that the representative "fairly and adequately protect the interests of the class.", The adequacy requirement prohibits named representatives from maintaining an action when the interests of the named representative diverge from the interests of class members. ${ }^{70}$

The failure of the named representative to satisfy the statute of limitations might compromise adequacy in two ways: First, a time bar might deprive the named representative of a stake in the outcome of the litigation, eliminating her individual incentive to protect the interests of the class. ${ }^{7}$ Courts commonly require that, at the time of certification, the named representative have an incentive to prosecute the

tangential if the same legal theory underlies the larger case).

67 See Koos v First National Bank of Peoria, 496 F2d 1162, 1164 (7th Cir 1974) ("Where it is predictable that a major focus of the litigation will be on an arguable defense unique to the named plaintiff ... then the named plaintiff is not a proper class representative."); Rodger $v$ Electronic Data Systems Corp, 160 FRD 532, 538-39 (E D NC 1995) (ruling that unique defense must make the named representative markedly different from those of the class). See also Sperling, 104 FRD at 9-10 (noting that named plaintiffs who failed to satisfy the statute of limitations would not be appropriate representatives of class members who satisfied the statute of limitations).

68 Compare Hilao, $103 \mathrm{F3d}$ at 774 (finding that there were no "relevant individual statuteof-limitations issues" and upholding district court decision to certify class), with Gary Plastic Packaging Corp v Merrill Lynch, Pierce, Fenner \& Smith, Inc, 903 F2d 176, 180 (2d Cir 1990) (noting that if the unique defense has the potential to dominate the litigation, typicality may not be satisfied).

69 FRCP 23(a)(4).

70 Amchem Products, Inc v Windsor, 521 US 591, 625 (1997) (“The adequacy inquiry under Rule 23(a)(4) serves to uncover conflicts of interest between named parties and the class they seek to represent."); General Telephone Co of the Southwest v Falcon, 457 US 147, 157-58 n 13 (1982) (noting the adequacy of representation requirement's concerns about conflicts of interest).

71 This assumes that the representative's primary interest in the litigation is an individual claim for damages. As noted earlier, representatives seeking injunctive relief may present a different case. 
class action vigorously. ${ }^{2}$ For example, the Seventh Circuit refused to certify a class action when the two named representatives had settled their individual claims against the defendant.

Second, a named representative might be more likely to fail to satisfy the statute of limitations in a case of ongoing or continuous harm. ${ }^{74}$ For example, it may be more difficult to determine when the action accrued in a case of ongoing pollution or sexual harassment. In such situations, the failure of the named representative to satisfy the statute of limitations might signal conflicts between the interests of the named representative and the class members. Courts have commonly found conflicts between current and future victims that rise to the level of compromising adequacy. ${ }^{75}$

Third, when the district court sits in diversity, differing statutes of limitations may create a conflict among putative class members. ${ }^{76}$ In many cases, the class representative and her attorney can select the relevant statute of limitations by selecting the forum. District courts sitting in diversity will apply the choice of law rules of the state in which they sit, and choice of law rules will determine the relevant substantive law. "State choice of law rules generally dictate that the forum state's statute of limitations will apply. ${ }^{7 s}$ The named representative

72 See Bennett $v$ Westfall, 640 F Supp 169, 170 (S D W Va 1986), affd 836 F2d 1342 (4th Cir 1988) (holding that a prisoner transferred out of jail was not a proper class representative to bring an action on behalf of inmates based upon conditions in the jail).

73 Davis v Ball Memorial Hospital Association, Inc, 753 F2d 1410, 1418 (7th Cir 1985) (finding that named plaintiffs "have received all of the relief they sought" against the defendant and "lack a personal stake in the outcome").

74 Class actions often consolidate the claims of those who have suffered from continuous or ongoing activity. Hilao $v$ Estate of Marcos, 103 F3d 767, 771 (9th Cir 1996) (aggregating the claims of those tortured over the course of fourteen years); National Assn of Govt Employees $v$ City Pub Serv Bd of San Antonio, 40 F3d 698, 702 (5th Cir 1994) (collecting discrimination claims under Title VII); Harding $v$ Tambrands Inc, 165 FRD 623, 626 (D Kan 1996) (combining the claims of toxic shock syndrome sufferers over the course of ten years).

75 Ortiz v Fibreboard Corp, 527 US 815, 119 S Ct 2295, 2319-20 (1999) (emphasizing that the district court should not certify a class containing present and future victims of asbestosrelated diseases without creating subclasses with individual representation); Amchem, 521 US at 626-27 (noting that the different interests between those injured in the distant past and those yet to become symptomatic required division into subclasses); In re Rhone-Poulenc Rorer, Inc, 51 F3d 1293, 1296-97 (7th Cir 1995) (noting that a district court refused to certify a single class of hemophiliacs infected from the blood supply because of differing dates of infection).

76 See Harding, 165 FRD at 628-29 (D Kan 1996) (noting the potential conflict caused by the selection of a statute of limitations but deciding that it did not rise to the level necessary to defeat adequacy).

77 Klaxon Co v Stentor Electric Manufacturing Co, Inc, 313 US 487, 496 (1941) (ruling that a federal court sitting in diversity must apply state choice of law rules); Erie Railroad Co $v$ Tompkins, 304 US 64, 78-79 (1938) (ruling that a federal court sitting in diversity must apply state substantive law).

78 See, for example, Keeton v Hustler Magazine, Inc, 549 A2d 1187, 1191-92 (NH 1988) (ruling that even under an interest analysis regime, the forum would apply its statute of limitations). See also Symeonides, Perdue, and von Mehren, Conflict of Laws at 371-78 (cited in note 37) (noting that under both the Restatement (First) of Conflict of Laws and the Restatement 
might choose a particular forum simply because its statute of limitations allows her to maintain her individual action, despite the fact that the forum would apply less favorable substantive law. The choice of substantive law might prejudice class members who could satisfy either state's statute of limitations. The named representative's choice of a forum may create subtle conflicts that would not be readily apparent when the absent member makes the decision to join or abstain from the class. ${ }^{79}$ These subtle choice of law problems may create conflicts between the class representative and class members that require judicial attention.

\section{Application of Rule 23 by District Courts}

Although Rule 23 establishes several analytically distinct requirements for certification, the United States Supreme Court has admitted that these inquiries tend to collapse upon one another. ${ }^{.0}$ District courts analyze the time-barred named representative under various Rule 23 labels and often justify a refusal to certify, in the alternative, under several Rule 23 requirements. District courts presented with large, complex class actions also often fail to attend carefully to "peripheral" statute of limitations issues. The following two cases illustrate that a district court's pragmatic application of Rule 23 can deviate substantially from the idealized approach presented in Parts II.A-C.

In Commander Properties Corporation v Beech Aircraft Corporation, an airplane owner ("Commander") brought an action against an airplane manufacturer ("Beech") for a wing joint problem. Commander sought certification for a class of all owners of certain Beech airplanes during the relevant time period.

(Second) of Conflict of Laws the district court will generally apply the forum's statute of limitations).

79 Arthur Miller and David Crump have made a similar argument. Miller and Crump worried that a class attorney's choice of forum might entail a substantive body of state law that favored some members of the class at the expense of others. Although the authors concluded that these conflicts would be too subtle and "ethereal" for consideration by most district courts, Miller and Crump argued that the existence of potential conflicts militated against the personal jurisdiction and choice of law principles outlined in Shutts. Arthur R. Miller and David Crump, Jurisdiction and Choice of Law in Multistate Class Actions after Phillips Petroleum Co. v. Shutts, 96 Yale L J 1, 66-67 (1986).

80 See Amchem Products, Inc $v$ Windsor, 521 US 591, 623 n 18 (1997) (noting the similarities between Rule 23(a)(3)'s commonality requirement and Rule 23(b)(3)'s predominance requirement); General Telephone Co of the Southwest v Falcon, 457 US 147, 157 n 13 (1982) (acknowledging that Rule 23's typicality, commonality, and adequacy requirements "tend to merge").

$81 \quad 164$ FRD 529 (D Kan 1995).

82 Id at 533. 
The district court initially acknowledged it could not "delve into the merits of the action," but the court proceeded to qualify that statement by saying the court must analyze the claims and defenses of the parties carefully. ${ }^{53}$ The court analyzed typicality and adequacy under a single subheading. The court noted that typicality did not impose a requirement that the legal claims be identical. After setting forth this uncontroversial legal proposition, the district court described the typicality requirement as "dovetail[ing]" with the adequacy requirement."

Beech argued that a statute of limitations defense unique to Commander should render him atypical. Commander arguably had actual notice of the wrong and injury before the other members of the class, and Commander's action was arguably barred by the statute of limitations. The district court refused to reach the question of typicality. $^{85}$

Instead, the district court held that the class action failed to satisfy Rule 23(b)(3)'s more specific and stringent requirement that questions of law or fact common to the class members must predominate over questions affecting individual class members. The district court ruled that "individual questions of law predominate with respect to ... statute of limitations defenses." ${ }^{, 86}$ The Commander court stated that individual questions of fact would also determine the outcome of the tolling claims and refused to certify the action as a $23(\mathrm{~b})(3)$ class action.

In Sperling $v$ Donovan, the district court treated the time-barred nature of the representative's claims casually, but its treatment of the issue critically affected the disposition of the case. ${ }^{89}$ In Sperling, the district court refused to certify a class action by two white named plaintiffs who alleged the Department of Labor had engaged in reverse discrimination. ${ }^{30}$ The district court emphasized that the isolated nature of the plaintiff's complaints made them markedly different or atypical from the remainder of the class." In reaching this decision, however, the district court refused to consider the named representative's time-barred claims." The district court naturally assumed it should consider the effects of a time bar when passing on typicality.

83 Id at 534

84 Id at 535 ("Atypical claims potentially create antagonistic interests, which will presumably affect Commander's ability to adequately represent the class.").

85 Id at 536-37.

86 Id at 538 .

87 Id at 538-39.

88 104 FRD 4 (D DC 1984).

89 Id at 9.

90 Id at 5-6,9.

91 Id at 7-9.

92 Id at 5 ("The question for the court is whether a class may be certified where, although a 
These district court cases portray the application of Rule 23 in practice. District courts consider multiple features of an action that could disqualify it for class treatment under multiple Rule 23 labels. District courts sometimes conflate analytic categories and attempt to avoid reaching the most difficult issues. These features of low-level decisionmaking make it difficult to distill the importance of deciding individual legal issues under clear analytic labels. Although this Comment's proposal would have generated the same outcome the district courts reached in these cases, class membership, typicality and adequacy each provide independent reasons for deciding how timebarred representatives should be treated.

\section{The District COURT SHOUld CONSIDER Time BARS AT CERTIFICATION AND ACT DECISIVELY IN THE FACE OF RULE 23 PROBLEMS}

Assuming that the named representative's time bar can create substantial problems under Rule 23, why would district courts not consider those problems at certification? District courts, at least initially, consider most other issues that have Rule 23 implications at certification. Certain advantages, such as judicial economy, fairness to absent class members, and fairness to the defendant flow naturally from applying the same decisionmaking schedule to the time-barred representative. Although district courts cannot investigate the representative's chances of success on the merits at the certification stage, a mandatory, but narrowly tailored, Rule 23 inquiry at certification could weed out some cases in which the named representative's claim is time-barred. Part III.A explores the advantages of applying the requirements of Rule 23 at certification.

If a district court decides the named representative does not satisfy Rule 23 requirements at certification, the district court can allow substitution, redefine the class, limit the size of the class, or strike the class complaint." Courts, choosing between striking the class complaint or ordering the plaintiffs' attorney to name a new representative frequently allow the plaintiffs' attorney to name another representative." Allowing substitution reinforces existing incentives for plaintiffs' attorneys to name few representatives and creates management difficulties for the district court. Part III.B details automatic substitution's dynamic, deleterious effects. This Comment then proposes that district

\footnotetext{
potential class can be identified, most of the individual plaintiff's claims are time-barred and cannot be revived under a continuing violation theory.").

93 Id at 9 (noting that "[m]ost of plaintiffs' claims in the case at bar are not timely" and moving on to examine only the timely claims to establish the atypicality of the representatives).

94 See notes $130-34$.

95 See text accompanying note 136.
} 
courts adopt a meaningful presumption towards striking the class complaints to create incentives for plaintiffs' attorneys to name multiple and diverse representatives.

\section{A. District Courts Should Consider Time Bars to the Named Representative at Certification}

If the district court can accurately decide some statute of limitations issues at certification, it will create considerable advantages for the judicial system and litigants. This Part proposes that the district court decide "easy cases" and identify "hard cases" at the certification stage. $^{36}$

Resolving the statute of limitations issue before certification has two advantages. First, a district court that discovers that a representative fails to satisfy the statute of limitations after discovery and crossmotions for summary judgment faces an unpalatable choice. The district court can decertify and waste the substantial resources expended in discovery, or the district court can allow substitution and risk unfairness to absent class members. Considering the issue before certification allows the district court to dismiss unfit named representatives before the parties or the court have invested heavily in the litigation." Second, time-barred representatives may not give the defendant effective notice of the scope and type of her liability within the statutory period. In the class action context, the Supreme Court has relied heavily on the named representative to justify tolling the statute of limitations for all class members. District courts that take the purposes of statutes of limitations seriously should consider these issues early and usually refuse substitution.

Finally, Rule 23 grants the district court sufficient authority to consider some statute of limitations questions at certification..$^{\infty}$ As explained in Part II, a representative's time bar directly bears on Rule 23 requirements. District courts have both the authority and competence to evaluate a named representative's time bar at certification.

\section{Courts can accurately decide easy cases at certification.}

District courts can resolve certain statute of limitations issues accurately at certification - the easy cases. A district court will find it difficult to decide other statute of limitations issues-the hard cases. When thinking about the relative prevalence of easy and hard statute of limitations questions, it might be useful to think along two dimen-

\footnotetext{
Part III.A.1 describes the distinction between easy and hard cases.

See Part III.A.2.

See Part III.A.3.

See Part III.A.4.
} 
sions. First, a statute of limitations issue might be either shared or individual. A district court's determination could either affect large groups of class members similarly (shared) or each individual class member differently (individual). Second, a shared statute of limitations issue might be legal or factual. ${ }^{100}$

Shared, legal statute of limitations issues will be easy for a district court to resolve at certification. For example, the parties may disagree about characterizing the cause of action as arising in contract or in tort, and the characterization will select the relevant statute of limitations. The characterization issue is a legal question that will critically affect the resolution of the statute of limitations defense for many class members. ${ }^{101}$ Additional discovery will not help a district court resolve the issue. District courts should decide this issue at certification.

Similarly, shared, factual cases might be easy for district courts to resolve at certification. ${ }^{102}$ For example, a plaintiff might claim that the defendant's fraudulent concealment of the wrong should toll the statute of limitations, and the relevant law might establish an objective standard for determining when the plaintiff should have discovered the injury and tolling should cease. In these cases, a district court's factual determination about when the plaintiff should have discovered the injury will resolve the statute of limitations issue for many members of the class. ${ }^{133}$

100 If discovery is necessary to resolve the issue, it should be considered factual. If discovery is unnecessary, it should be considered legal. Individual statute of limitations issues do not sort themselves into these convenient categories, however, because it is difficult to imagine a statute of limitations question that would call for a separate legal determination for every class member. Consequently, the district court should encounter three types of statute of limitations issues at certification: shared, legal questions; shared, factual questions; and individual questions.

101 Consider Hilao v Estate of Marcos, 103 F3d 767 (9th Cir 1996), where the district court determined that the statute of limitations for torture claims against former Philippine President Marcos had been tolled during his tenure in office. The district court's determination was an interpretation of the Torture Victim Protection Act and affected all class members. Resolving the statute of limitations question prior to certification allowed the court to avoid the implications of a representative's time bar for Rule 23. Id at 772-73.

102 District courts will often look to evidence to determine the appropriateness of certification, although they should not base their decisions on the plaintiffs' likelihood of success on the merits. See Caridad v Metro-North Commuter Railroad, 191 F3d 283, 292-93 (2d Cir 1999) (looking to statistical evidence provided by the plaintiffs to determine their fitness as representatives in a class action based on disparate impact discrimination under the Civil Rights Act of 1964). See also Castano v American Tobacco Co, 84 F3d 734, 744 (5th Cir 1996) (referring to Eisen and noting that "[a] district court certainly may look past the pleadings to determine whether the requirements of rule 23 have been met"); Chateau de Ville Productions, Inc v TamsWitmark Music Library, Inc, 586 F2d 962,965-66 (2d Cir 1978) (remarking on the ability to conduct additional discovery of named representatives for the certification hearing); Wright, Miller, and Kane,7B Federal Practice and Procedure at $\$ 1785$ (cited in note 12) ("Going beyond the pleadings is necessary, as a court must understand the claims, defenses, relevant facts, and applicable substantive law in order to make a meaningful determination of the certification issues.").

103 See Great Rivers Cooperative v Farmland Industries, Inc, 120 F3d 893, 896-99 (8th Cir 1997) (affirming the district court's determination that all class members should have had notice 
Shared, factual issues might be more difficult than shared, legal issues because they require partial discovery and might bear a greater resemblance to an inquiry into the merits. Nonetheless, limited factual inquiries may save the needless expense of full discovery.

District courts will also face more difficult, individual questions. Individual statute of limitations issues might be more difficult to resolve at certification. For example, a district court will have difficulty determining when each individual member of a class discovered her injury. ${ }^{104}$

The categories shared factual, shared legal, and individual do not provide a comprehensive taxonomy of statute of limitations issues. These distinctions do, however, roughly capture a sense that district courts have the capacity to resolve some statute of limitations issues accurately very early in the litigation.

If a district court refuses to consider time bars to the named representative at certification, it should offer a compelling reason for doing so. ${ }^{105}$ Although district courts should not resolve every statute of limitations issue at certification, simply identifying difficult questions could facilitate management. For example, the question of whether a defendant fraudulently concealed her tortious behavior might turn on complex substantive issues that the district court wishes to reserve until after full discovery. Identifying the issues, however, will allow the district court to make certain the class is composed of and represented by parties who meet the statute of limitations with and without the fraudulent concealment exception. This places all parties and the court in a better position.

Allowing district courts to consider these issues at certification should not increase the costs of erroneously denying certification. This discretionary approach relies on modest assumptions about a district court's decisionmaking abilities. Even if we do not have much confi-

of the wrong committed by the defendant).

104 See, for example, Commander Properties, 164 FRD at 529, where the district court refused certification because determining when the class members discovered the harm would require individual findings of fact.

105 Forcing the district court to enter findings on critical certification issues is not novel. The Ninth Circuit and the Fourth Circuit have emphasized the importance of findings by a district court when it refuses certification. See Gibson v Local 40 Supercargoes and Checkers, 543 F2d 1259,1263 \& n 2 (9th $\mathrm{Cir} 1976$ ) (refusing to defer to a trial court's certification decision given a lack of findings); Ballard $v$ Blue Shield of Southern West Virginia, Inc, 543 F2d 1075, 1080 (4th Cir 1976) (remanding because " $[t]$ he district court ... did not explain, other than in the most general terms, why the class did not satisfy the requirements of Rule 23"). Findings by the district court also enable litigants to determine whether an appeal of the certification decision is warranted and enable appellate courts to review the certification decision. See Wright, Miller, and Kane, 7B Federal Practice and Procedure $\$ 1785$ at 119 \& n 49 (cited in note 12). Forcing the district court to enter findings when granting a motion for certification could clarify the defendant's issues on appeal in the same manner. 
dence in the ability of district courts to resolve difficult cases prior to certification, we should have confidence in their ability to identify difficult cases at this stage and bracket them for later resolution. ${ }^{106}$ Simply identifying the issues will aid the court in making management decisions.

2. Evaluating the time bar after certification risks wasting judicial resources and prejudicing absent class members.

If district courts can dismiss improper classes earlier in the litigation rather than later, it will promote the efficiency goals of Rule 23. As the litigation progresses beyond certification, notice fees and attorneys' fees increase. ${ }^{107}$ The extensive discovery process that typifies complex class action litigation also consumes significant litigant and judicial resources. ${ }^{103}$ Rule 23 seeks to promote judicial and litigant economy by allowing the consolidation of many individual actions into a single, common proceeding. ${ }^{109}$ Dismissing a class action far into the process will undermine this central purpose.

Recognizing this, many courts that fail to discover the named representative's time bar until late in the litigation refuse to dismiss the class complaint. Instead, these courts allow another class member to substitute and serve as the named representative. Substitution avoids wasting resources, but has three serious limits.

First, in some cases, automatically relying on substitution may risk binding absent class members to an unfair settlement. Certification presents a major hurdle to most class actions, and settlement often follows closely on the heels of certification. ${ }^{120}$ A district court that fails to consider statute of limitations issues at certification may inadver-

106 See Ruhrgas AG v Marathon Oil Co, 526 US 574, 119 S Ct 1563, 1571-72 (1999) (expressing confidence in the ability of the district court to distinguish between hard and easy cases of personal and subject matter jurisdiction early in the litigation).

107 Notice fees are only required in Rule 23(b)(3) class actions, but district courts have the discretion to require the parties to issue notice in other class actions. Compare FRCP 23(b)(3) with FRCP 23 (d)(2). Several courts have noted the large expense of notice costs. See Eisen, 417 US at 167 (noting that individual notice could cost as much as $\$ 315,000$ ). See also P.D.Q. Inc of Miami v Nissan Motor Corp in USA,61 FRD 372, 377 (S D Fla 1973) (describing notice costs of over $\$ 300,000$ and substantial discovery costs), affd, 577 F2d 910 (5th Cir 1978).

108 See Edward Brodsky, Discovery Abuses: A Shifting Target?, NY L J 3 (Apr 9, 1997) (indicating that discovery can account for 80 percent of total litigation costs).

109 The Advisory Committee Notes describe class actions as conserving judicial resources and preventing redundancy. Advisory Committee's Notes to the 1966 Amendments in Federal Rules of Civil Procedure 259-64 (Foundation 1999). See also American Pipe \& Construction Co $v$ Utah, 414 US 538,553-54 (1974) (describing the prevention of duplicative actions as the central purpose of Rule 23).

110 Ortiz v Fibreboard Corp, 527 US 815, 119 S Ct 2295, 2317-18 (1999) (describing enormous pressures for plaintiffs' counsel to settle large, complex class actions in the wake of certification). See also In re Rhone-Poulenc Rorer, Inc, 51 F3d 1293, 1298-99 (7th Cir 1995) (describing similar pressures on defendants). 
tently distribute settlement proceeds to time-barred class members. Such inadvertent distributions will obviously either reduce the amount awarded to class members with timely claims ${ }^{111}$ or impose a disproportionate level of liability on the defendant. Although district courts independently review settlement offers, the Supreme Court has stated that this independent review is not sufficient to guard the interests of class members. ${ }^{12}$ A district court should investigate the named representative's time bar as a factor critical to the fairness of certification. Identifying these issues early and deciding them correctly will reduce the risk of an unfair settlement.

Second, even if a case progresses to trial, certification could compromise the interests of absent class members. A representative's time bar often coincides with difficult choice-of-law issues or ongoing harms. In such cases, the representative's time bar may signal more fundamental problems within the class that might compromise the due process interests of absent class members. In such cases, certification in the face of a representative's time bar might compromise Rule 23 requirements. ${ }^{113}$

Third, as explained in Part III.B, automatically allowing substitution will exaggerate current incentives for class attorneys to name few, non-diverse representatives and exacerbate management problems. This will frustrate district courts' efforts to manage class actions effectively and guarantee the procedural interests of defendants and absent class members.

Considering statute of limitations issues at the certification stage avoids the unpalatable alternatives of late dismissal of the class or late substitution.

3. Preserving the purposes of statutes of limitations.

A time-barred class representative may not provide the defendant with sufficient notice of the number and types of potential claims. After the Supreme Court's decision in American Pipe \& Construction Co $v$ Utah,${ }^{14}$ filing a class action tolls the statute of limitations for all members of the putative class, even if the district court ultimately de-

111 For example, in a limited fund class action, expanding the class of plaintiffs who can recover will necessarily reduce the amount recovered by each individual plaintiff This may be more generally true in any Rule 23(b)(3) class action where the defendant faces bankruptcy. See Ortiz, $119 \mathrm{~S} \mathrm{Ct}$ at 2311-12 (describing unique problems with limited fund class action and bankrupt defendants).

112 Ortiz, $119 \mathrm{~S} \mathrm{Ct}$ at 2316 (1999) ("[A] fairness hearing under Rule 23(e) is no substitute for rigorous adherence to those provisions of the Rule 'designed to protect absentees."); Amchem Products, Inc v Windsor, 521 US 591, 621-22 (1997) (emphasizing the importance of preserving Rule 23(a) requirements despite the fairness hearing provided for in Rule 23(e)).

113 See Part II.C.

114414 US 538 (1974). 
nies certification. ${ }^{115}$ The American Pipe tolling rule promotes the efficiency goals of Rule 23: if the statute of limitations continued to run for putative class members after the filing of the action, putative class members would need to file duplicative and wasteful individual actions to preserve their legal rights.

The American Pipe tolling rule simultaneously preserves the traditional purposes of statutes of limitations. When a named representative commences a class action within the statutory period, she notifies the defendants of the type of claim being brought and the approximate scope of those claims. ${ }^{117}$ This notice prevents unfairness to the defendant and gives the defendant an opportunity to preserve relevant evidence. ${ }^{\text {118 }}$

The named representative's individual claim is crucial to defining the scope of the class complaint and providing the defendant with accurate notice of the scope and type of the tolled liability. ${ }^{119}$ If the named representative fails to satisfy the statute of limitations, then the representative also fails to notify the defendant accurately of the scope and type of her liability to class members with timely claims. ${ }^{120}$ Months or even years after the filing of the initial complaint, the defendant may face a headless and mixed class, composed of individuals with both timely and untimely claims. ${ }^{121}$ Certification despite the failure of the named representative to satisfy the statute of limitations will undercut American Pipe's delicate balance between efficiency and the purposes of statutes of limitations. ${ }^{12}$

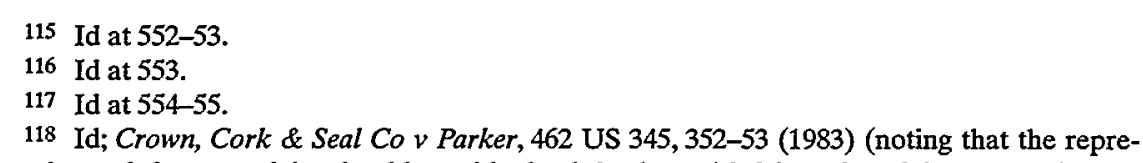
sentative and class complaint should provide the defendant with fair notice of the type and scope of liability).

119 See American Pipe, 414 US at 552-55 (1977) (emphasizing that the decision was restricted to cases where the class failed for lack of numerosity rather than the representative's lack of adequacy or typicality).

120 See Davis v Bethlehem Steel Corp, 600 F Supp 1312, 1318 (D Md 1985) ("[T] $]$ he claims of the named representatives of the putative class ... must have been alleged sufficiently clearly to establish the specific parameters ... of the class claims."). Charles Sawyer has suggested that when the class claim and the named representative's individual claim differ substantially from the claims of putative class members, then the class claim may fail to provide the defendant with sufficient notice under American Pipe. Charles F. Sawyer, Class Actions and Statutes of Limitations, 48 U Chi L Rev 106, 114 (1981).

121 The Fourth Circuit recognized that dismissing the named plaintiffs would leave a "headless lawsuit," but remanded the case to the district court to allow substitution, and ignored any problems that might arise from American Pipe tolling. See Goodman v Schlesinger, 584 F2d 1325, 1332-33 (4th Cir 1978).

122 Substitution will not remedy the defect. The claims for all class members will be tolled upon filing the class action. If the court allows the substitution of a class member whose claim was not time-barred on the date of filing, the defendant will be caught off guard. Consider Haas v Pittsburgh National Bank, 526 F2d 1083, 1097-98 (3d Cir 1975) (noting that when the court al- 


\section{Using Rule 23 to assess the statute of limitations question at certification.}

Although a named representative's failure to satisfy the statute of limitations seems to speak to the likelihood of her success on the merits, making it inappropriate for consideration at the certification stage, Eisen ${ }^{123}$ permits the district court to inquire narrowly whether the statute of limitations defense compromises Rule 23 requirements. The named representative's time bar can be evaluated with reference to Rule 23 requirements rather than the named representative's ultimate chances of success on the merits. Although the Supreme Court refuses to allow district courts to reach conclusions about the ultimate viability of representatives' claims, the Supreme Court has also repeatedly insisted that the named representative "be a part of the class and 'possess the same interest and suffer the same injury' as the class members." 124 A time-barred representative may suffer serious deficiencies as a representative or signal serious deficiencies in the class. ${ }^{125}$ The district court certainly has the authority to inquire about the existence of defenses that might compromise the requirements of Rule $23 .^{126}$

The discretionary nature of the statute of limitations inquiry should eliminate concerns about reaching substantive conclusions prematurely. Courts can always justify refusing to consider the statute of limitations defense during certification because full discovery is necessary to determine the validity of the defense. Courts could also avoid preliminary conclusions about the statute of limitations if it fears that such conclusions would unfairly prejudice the defendant. For example, if a district court fears that determining whether the defendant fraudulently concealed her tortious conduct would "color the subsequent proceedings and place an unfair burden on the defendant," bility of compromising notice to the defendant. ${ }^{128}$ A mere justification

lows substitution for a named representative, American Pipe tolling will protect the claim of the new named representative and all members of the class).

123417 US 156 (1974). See text accompanying notes 46-49.

124 East Texas Motor Freight System, Inc v Rodriguez, 431 US 395, 403 (1977), quoting Schlesinger $v$ Reservists Committee to Stop the War, 418 US 208, 216 (1974).

125 See Part II.

126 Courts often make detailed factual findings for the purposes of certification. These courts routinely conduct discovery and go beyond the pleadings to determine whether classes and representatives satisfy Rule 23 requirements such as predominance. See note 102 . By contrast, in Eisen, the district court attempted to perform an operation not sanctioned by Rule 23, namely, shifting notice costs from the plaintiffs to the defendants. Eisen, 417 US at 178.

127 Eisen, 417 US at 178.

128 Part III.A.3 explains how allowing representation by a plaintiff who fails to satisfy the statute of limitations may result in unfairness to the defendarit. 
by the court, however, might have the benefit of identifying the potential statute of limitations issues. ${ }^{129}$

\section{B. District Courts Should Adopt a Meaningful Presumption Towards Dismissing the Class Complaint}

If a district court decides the named representative is inappropriate, it has several options. The district court can allow substitution or intervention by another class member to remedy the defect and leave the class unchanged ${ }^{130}$ divide the class into subclasses, ${ }^{131}$ limit the size of the existing class, ${ }^{122}$ or strike the class and allow the action to continue individually. ${ }^{133}$ A district court theoretically has the discretion to revoke certification and dismiss the class action throughout the trial. ${ }^{134}$ In practice, however, the class assumes an independent status after certification, and the district court is much less likely to dismiss. ${ }^{135}$ Courts that find the named representative inappropriate because her claim is time-barred typically allow substitution or intervention to remedy the named representative's defects. ${ }^{136}$ These courts, however,

129 See note 105.

130 Robinson $v$ Sheriff of Cook County, 167 F3d 1155, 1158 (7th Cir 1999) (arguing that district courts should simply allow substitution when events subsequent to certification reveal the inappropriateness of the named representative).

131 In re Diamond Shamrock Chemicals Co, 725 F2d 858, 861 (2d Cir 1984) (creating subclasses to resolve difficult choice of law problems).

132 Shvartsman v Apfel, 138 F3d 1196, 1201 (7th Cir 1998) (upholding a district court's decision to limit the class to all resident aliens receiving food stamps who lived in the Seventh Circuit rather than allowing the action to continue as a nationwide class action); Wright, Miller, and Kane,7A Federal Practice and Procedure $\$ 1760$ at 127-28 (cited in note 12) (noting the court's discretion to limit or redefine the class).

133 Hardy $v$ City Optical Inc, 39 F3d 765, 772 (7th Cir 1994) (affirming the denial of certification and allowing the suit to continue individually); Wright, Miller, and Kane, 7A Federal Practice and Procedure $\S 1760$ at 131 (cited in note 12) (noting the court's option to strike the class and allow plaintiffs to proceed individually).

134 See note 28.

135 For example, the district court will often allow an action to proceed if the named representative's claim becomes moot after certification but will require intervention or substitution if the named representative's claim becomes moot prior to certification. Comer v Cisneros, 37 F3d 775,798 (2d Cir 1994) (noting that an individual named plaintiff can continue to represent the interest of the class after certification, even if the plaintiff's individual stake has disappeared). Courts will also ignore the post-trial inadequacy of a named plaintiff Falcon, 457 US at 156 (noting that the case would be different if the named plaintiffs appeared inadequate after certification); Thurston v Dekle, 531 F2d 1264, 1270 (5th Cir 1976) (upholding class certification when named plaintiff's failure to satisfy standing requirement was caused by legal interpretation subsequent to his suit, and the new law was unknown both to plaintiff and to trial court), vacated on other grounds, 438 US 901 (1978).

136 International Woodworkers of America v Chesapeake Bay Plywood Corp, 659 F2d 1259, 1270 (4th Cir 1981) (reversing the district court's denial of certification to allow substitution by class members whose claims were not time-barred); Goodman v Schlesinger, 584 F2d 1325, 133233 (4th Cir 1978) (remanding to allow substitution after named plaintiffs were dismissed because the evidence failed to show that they suffered any discrimination); Cox $v$ Babcock and Wilcox $\mathrm{Co}, 471 \mathrm{~F} 2 \mathrm{~d} \mathrm{13,16}$ (4th $\mathrm{Cir} 1972$ ) (affirming the lack of an individual claim but remanding to al- 
usually make this decision without thoroughly examining the incentive effects created by allowing substitution or intervention. ${ }^{137}$ The district court's decision to allow substitution or intervention should consider the notice and fairness concerns mentioned in Part III.A in the context of the incentives created for plaintiffs' attorneys. ${ }^{139}$

\section{Incentives currently faced by the class attorney.}

If a district court simply allows substitution, it will preserve incentives for plaintiffs' attorneys to name few representatives while simultaneously defining classes vaguely and broadly. The current system encourages plaintiffs' attorneys to name fewer representatives in two ways. First, plaintiffs' attorneys have strong incentives to bring suits quickly, without investing significant resources. Plaintiffs' attorneys are generally members of small firms with very few resources. ${ }^{139}$ Initially underinvesting in a large number of actions may be the best way for a class attorney to diversify risk. Reducing the amount invested in any given case allows the class attorney to spread risk among a large number of cases: this prevents a single bad outcome from destroying the attorney's entire practice. ${ }^{140}$ Consequently, the plaintiffs' attorney

low a new class member to step forward).

137 See, for example, Peoples $v$ Wendover Funding, Inc, 179 FRD 492, 499-502 (D Md 1998) (dismissing a time-barred representative without creating subclasses or dealing with the more complex and subtle issues). See also John C. Coffee, Jr., The Regulation of Entrepreneurial Litigation: Balancing Fairness and Efficiency in the Large Class Action, $54 \mathrm{U}$ Chi L Rev 877, 877 (1987) ("[C]ivil procedure scholars ... have as a group been reluctant to engage explicitly in incentive-based reasoning.").

138 An initial reservation: Complex incentives and difficult empirical questions might limit our ability to gauge the dynamic effects of any procedural change confidently. However, the difficulty of this task should not excuse courts and commentators from evaluating this critical variable. Instead, the uncertainty argues in favor of a minimalist approach. Uncertainty should make us skeptical of attempts to reshape class action law radically. Consider Ortiz v Fibreboard Corp, 527 US $815,119 \mathrm{~S} \mathrm{Ct} 2295,2320-21$ (1999) (chastising lower courts for liberally experimenting with the text of Rule 23). When addressing these issues, we should act incrementally. A minimalist approach by individual district courts might enable us to learn more about the complex effects of procedural changes and presumptions on the incentives of class attorneys. At the same time, a minimalist approach will avoid creating large unintended negative consequences. Consider Cass R. Sunstein, One Case at a Time: Judicial Minimalism on the Supreme Court 52-53 (Harvard 1999) (advocating "shallow and narrow decisions" to counteract the difficulties posed by cognitive limitations); Dietrich Dörner, The Logic of Failure: Recognizing and Avoiding Error in Complex Situations 1-10 (Addison-Wesley 1997) (Rita and Robert Kimber, trans) (discussing the difficulties even the most educated and professional people have in anticipating bad consequences of social engineering). With that in mind, we might make some cautious statements about the possible incentive effects of allowing automatic substitution or intervention when the named representative fails to satisfy the statute of limitations.

139 John C. Coffee, Jr., Understanding the Plaintiffs Attorney: The Implications of Economic Theory for Private Enforcement of Law through Class and Derivative Actions, 86 Colum L Rev 669,704-12 (1986) (discussing the incentives for plaintiff's firms to engage in "portfolio diversification" due to their small sizes and status as repeat players).

140 See id. 
might minimize search costs by naming fewer representatives and minimize research costs by defining the class broadly and vaguely. Second, naming a larger number of representatives risks shifting decisionmaking power from the plaintiffs' attorney into the hands of the class representatives. ${ }^{14}$

The current system also encourages plaintiffs' attorneys to define classes broadly and vaguely. Defining the class too broadly places burdens on the defendant, the court, and absent class members rather than the plaintiffs' attorney; defining the class too narrowly deprives the plaintiffs' attorney of a portion of the potential recovery. The larger the class, the greater the potential recovery and attorneys' fees. ${ }^{1.2}$ In addition, American Pipe tolling encourages the class attorney to define the class broadly. When a complaint names a broader class, the statute of limitations will be tolled for a larger number of people. ${ }^{1.3}$

These combined incentives can create an inefficient dynamic: plaintiffs' attorneys will systematically create large, unwieldy classes without naming diverse representatives. Unfortunately, the plaintiffs' attorney, rather than the court, is in a better position to divine potential conflicts among the class, differences in the class, and effective management devices.

\section{Information-eliciting penalty defaults.}

District courts should adopt a meaningful presumption towards dismissing a class when all of the named representatives fail to satisfy the statute of limitations. This presumption would punish individual plaintiffs' attorneys who brought class actions naming only timebarred representatives. It would establish incentives for plaintiffs' attorneys to consider statute of limitations issues more carefully and name multiple, diverse representatives.

Dismissing these complaints would impose two costs on plaintiffs' attorneys who file class actions naming time-barred representatives. First, plaintiffs' attorneys who file a class action and lose the certifica-

141 See Macey and Miller, 58 U Chi L Rev at 41 (cited in note 21) (suggesting plaintiffs' attorneys select named representatives who will allow the attorney to control the course of litigation).

142 Ortiz, $119 \mathrm{~S} \mathrm{Ct}$ at 2317-18 (recognizing that the prospect of a large recovery and enormous fees may influence the behavior of the plaintiffs' attorney). Some courts have replaced the percentage of recovery scheme with a lodestar scheme that awards plaintiff's attorneys the time reasonably spent on a matter, but incentives remain to define a class broadly. Coffee, $54 \mathrm{U}$ Chi $\mathrm{L}$ Rev at 888-89 (cited in note 137) (describing the lodestar system). An attorney can justify higher levels of staffing and spending more time on a matter if the class is larger.

143 Haas $v$ Pittsburgh National Bank, 526 F2d 1083, 1097-98 (3d Cir 1975) (noting that when the court allows substitution for a named representative, American Pipe tolling will protect the claim of the new named representative and all members of the class). 
tion hearing risk reducing the size of their class fee. ${ }^{14}$ The market for class actions is extremely robust, ${ }^{145}$ and plaintiffs' attorneys have few resources to dedicate to uncovering potential class actions. ${ }^{146}$ Plaintiffs' attorneys lower search costs by relying heavily on the news media and filings by other attorneys to uncover profitable class actions. Filing the class action signals the availability of a profitable class action to other attorneys; these attorneys will race to find representatives and file suit. $^{1.7}$ If the plaintiffs' attorney loses the certification hearing, then it gives competing attorneys additional time to find representatives and attempt to share in the class fee.

Second, each additional certification hearing costs plaintiffs' attorneys. A second certification hearing will require additional legal research, discovery, and search costs. ${ }^{14}$ This presumption may reduce the absolute number of class claims filed, but it should not substantially reduce the number of meritorious claims filed. Many plaintiffs' attorneys fiercely compete to litigate a limited number of profitable class actions. ${ }^{149}$ At first cut, this minimal cost should not substantially reduce the number of class attorneys or the number of class suits filed.

Even if the presumption lowers the absolute number of class actions filed, it should shift more resources to meritorious claims. Raising standards for certification will force the plaintiffs' attorney to direct resources prior to certification more carefully. Carefully organizing frivolous claims constitutes an unnecessary cost. If the plaintiffs' attorney has a meritorious class claim, however, the expected value of the case is higher, and the district court's certification denial will draw fierce competition from other attorneys. When district courts reject hastily organized meritorious claims, the plaintiffs' attorney will lose a larger share of the class fee to competitors. The marketplace will reward plaintiffs' attorneys for accurately sorting meritorious and

144 John C. Coffee, Jr., The Unfaithful Champion: The Plaintiff as Monitor in Shareholder Litigation, 48 L \& Contemp Probs 5, 50 (Summer 1985) (noting that when multiple plaintiffs' attorneys appear to represent the class, the plaintiffs' attorneys must divide the contingency and their individual shares decline). tions).

145 Id (describing the competitiveness of the market for antitrust and securities class ac-

146 Coffee, 86 Colum L Rev at 704-12 (cited in note 139) (noting the small size of most plaintiffs' firms).

147 Id at 681-82 (describing most entrepreneurial litigation as sparked by a high-visibility event that makes the news or the initiation of suit by another party). In the securities arena, class actions often follow Securities and Exchange Commission proceedings or a bankruptcy. See John E. Kennedy, Securities Class and Derivative Actions in the United States District Court for the Northern District of Texas: An Empirical Study, 14 Houston L Rev 769, 824 (1977) (reporting that 50 percent of class and derivative actions piggybacked on prior proceedings).

148 Macey and Miller, 58 U Chi L Rev at 66 (cited in note 21) (identifying costs associated with finding each additional named representative and proving she meets the requirements of Rule 23(a) and labeling them deadweight losses).

149 Coffee, 48 L \& Contemp Probs at 50 (cited in note 144). 
frivolous claims earlier, and it will reward early investments in meritorious class claims.

Encouraging more careful organization of class actions and naming multiple, diverse representatives will have several important advantages. First, the plaintiff's attorney has more information about the composition of the class and the facts that gave rise to the suit. Early in the action, the district court has few opportunities to conduct extensive fact finding. ${ }^{150}$ If a district court can force the plaintiffs' attorney to disclose most of the relevant information, then the court can make more informed management decisions early in the litigation.

Second, this presumption facilitates the notice requirements of American Pipe. A larger and more diverse set of named representatives will give the defendant better notice of the potential number and type of claims encompassed by the putative class. ${ }^{251}$

Third, this presumption forces a clarification of the class itself. A more diverse set of named representatives will make conflicts more readily apparent and facilitate the early development of subclasses. Even harsh critics of the current adequacy and typicality requirements admit that the named representative provides the district court with information about the internal composition of the class. ${ }^{152} \mathrm{~A}$ larger and more diverse set of named representatives will reveal internal class conflicts earlier and allow the district court to manage the case more effectively.

\section{CONCLUSION}

Timing matters. All courts agree that a time-barred representative fails to satisfy the requirements of Rule 23. Refusing to allow districts court to consider easy statute of limitations issues at certification forces the court to choose later between wasting substantial resources or prejudicing absent class members. Furthermore, if the named representative is later dismissed, then the initial class complaint does not provide the defendant with notice of the scope and type of her liability within the statutory period. A carefully limited inquiry into the named representative's time bar could avoid reaching substantive conclusions about the representative's chances of success on the merits. At certification, district courts should narrowly investigate whether

150 For a description of the limited information available to the trial court, see Macey and Miller, $58 \mathrm{U}$ Chi L Rev at 46 (cited in note 21).

151 See Part III.A.3.

152 Macey and Miller, $58 \mathrm{U}$ Chi L Rev at 76 (cited in note 21) ("The divergence in interests between the named plaintiff and other class members is rather a function of a more fundamental problem, namely the divergence in interests among members of the class."). 
a time bar to the named representative's action will compromise Rule 23 requirements.

If district courts routinely consider the matter at certification, then they will often face the question of what to do with a headless class. Rather than ordering remedial steps, these courts should strike the class action. By striking the class complaint when the named representative fails to satisfy the statute of limitations, district courts can encourage plaintiffs' attorneys to name multiple and diverse representatives, facilitating more effective management of the class action. 